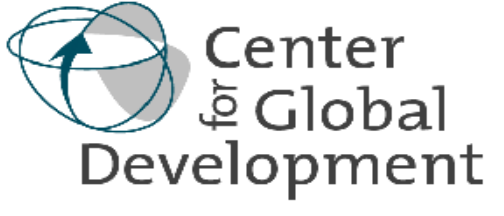

Working Paper Number 165

March 2009

Schooling Inequality, Crises, and Financial Liberalization in Latin America

By Jere R. Behrman, Nancy Birdsall, and Gunilla Pettersson

\begin{abstract}
Latin America is characterized by high and persistent schooling, land, and income inequalities and extreme income concentration. In a highly unequal setting, powerful interests are more likely to dominate politics, pushing for policies that protect privileges rather than foster competition and growth. As a result, changes in policies that political elites resist may be postponed in high-inequality countries to the detriment of overall economic performance.

This paper examines the relationship between structural, high inequality-measured by high levels of schooling inequality — and liberalization of the financial sector for a sample of 37 developing and developed countries for the period 1975 to 2000. Liberalization of the financial sector can be broadly thought of in the Latin American pre-2000 context as opening credit markets that earlier were largely restricted, including by ending directed credit. For our measure of structural inequality we use data on schooling Gini coefficients that have not previously been used in this context. In our sample, we find that increases in financial liberalization were associated with bank crises and other domestic and external shocks, and that higher schooling inequality reduces the impetus for liberalization brought on by bank crises.
\end{abstract}

The Center for Global Development is an independent, nonprofit policy research organization that is dedicated to reducing global poverty and inequality and to making globalization work for the poor.

Use and dissemination of this Working Paper is encouraged; however, reproduced copies may not be used for commercial purposes. Further usage is permitted under the terms of the Creative Commons License. The views expressed in this paper are those of the author and should not be attributed to the board of directors or funders of the Center for Global Development.

www.cgdev.org 
Jere R. Behrman, Nancy Birdsall, and Gunilla Pettersson. 2009. "Schooling Inequality, Crises, and Financial Liberalization in Latin America." CGD Working Paper 165. Washington, D.C.: Center for Global Development http://www.cgdev.org/content/publications/detail/1421333/ 


\title{
Schooling Inequality, Crises, and Financial Liberalization in Latin America
}

\author{
Jere R. Behrman, Nancy Birdsall, and Gunilla Pettersson ${ }^{1}$
}

\begin{abstract}
Latin America is characterized by high and persistent schooling, land, and income inequalities and extreme income concentration. In a highly unequal setting, powerful interests are more likely to dominate politics, pushing for policies that protect privileges rather than foster competition and growth. As a result, changes in policies that political elites resist may be postponed in high-inequality countries to the detriment of overall economic performance.

This paper examines the relationship between structural, high inequality—measured by high levels of schooling inequality —and liberalization of the financial sector for a sample of 37 developing and developed countries for the period 1975 to 2000. Liberalization of the financial sector can be broadly thought of in the Latin American pre-2000 context as opening credit markets that earlier were largely restricted, including by ending directed credit. For our measure of structural inequality we use data on schooling Gini coefficients that have not previously been used in this context. In our sample, we find that increases in financial liberalization were associated with bank crises and other domestic and external shocks, and that higher schooling inequality reduces the impetus for liberalization brought on by bank crises.
\end{abstract}

\footnotetext{
${ }^{1}$ Jere R. Behrman is W.R. Kenan, Jr. Professor of Economics at University of Pennsylvania; Nancy Birdsall is President of the Center for Global Development in Washington, D.C.; and Gunilla Pettersson is a PhD student at the Department of Economics, University of Sussex, UK. This paper is based on a note prepared for the CGD Task Force on Helping Reforms Deliver Growth in Latin America, generously supported by the Open Society Institute. We would like to thank Abdul Abiad for sharing the financial liberalization data, Yan Wang for sharing the schooling Gini coefficient data with us, and Michael Clemens and participants at a CGD Research Seminar for useful comments.
} 
Center for Global Development | www.cgdev.org 


\section{Introduction}

Recent studies suggest that inequality, contrary to once-conventional wisdom, is bad for economic growth and development (Cornia and Court 2001; Easterly 2002). Latin America as a region may have been a particular victim of this negative relationship. Birdsall and Londoño (1997) find a negative relationship between inequality of schooling and inequality of land ownership with growth in a cross-country study. They show that Latin America is not a negative outlier in the effect of high income inequality on growth once inequality of these two assets is taken into account.

For Latin America, de Janvry and Sadoulet (1999) and Carter (2004) report the persistence for decades of a relationship between past land inequality and current income inequality. Behrman, Birdsall, and Szekely (2000) find high persistence of schooling inequality across generations in Latin America compared to the U.S. These studies suggest that Latin America suffers from a longstanding problem of inequality of assets, of schooling and of income.

The question we address in this paper is whether there is a relationship between schooling inequality, meant to capture the concentration of power with a small political elite, and the undertaking of policy changes that liberalize and make more open the financial sector. As far as we know this question has not heretofore been addressed for Latin America or for any other region.

We begin by documenting the extent and nature of inequality and liberalizing efforts in Latin America. Then we discuss the motivation for our interest in the relationship between inequality and financial policy shifts, and set out the simple framework used to test this relationship before presenting our regression results. We end with a brief conclusion.

\section{Inequality and Measures of Reform in Latin America}

In this section we describe the extent of inequality in Latin America, the evolution of economic reforms, and the financial liberalization index that we use to construct the dependent variable in our simple model of inequality and financial liberalization. 
Income, Schooling, and Land Inequality

Latin America has a long history of persistent and high inequality. In the 1980s, income inequality measured by the income Gini coefficient ranged from a "low" of 0.41 in Argentina to a high of 0.57 in Brazil. Average income inequality in the region as a whole for this period was 0.50 compared to 0.30 for high-income OECD countries, and 0.45 for East Asia. Land inequality was also extremely high in Latin America with an average land Gini coefficient of 0.84. By 2000, average income inequality in Latin America had risen to 0.54, in East Asia to 0.49 , and in high-income OECD countries to 0.32 .

Schooling inequality, measured in terms of grades of schooling attained across adults, was also high in Latin America in the early to mid-80s, averaging 0.46 (schooling Gini coefficient) compared to 0.29 in high-income OECD countries, and 0.39 for East Asia. ${ }^{2}$ The countries with the highest schooling inequality were both among the poorest in the region (Guatemala, Honduras and Nicaragua), and the richest (Mexico). Average schooling inequality has declined over time, in 2000, the schooling Gini for Latin America as a region was 0.42, for East Asia 0.35, and for high-income OECD countries 0.26.

The decline in schooling inequality in nearly all developing countries since the 1980s is partly due to the fact that most governments have increased spending on basic education. In Latin America the median schooling Gini coefficient has fallen from 0.42 in 1980 to about 0.40 in 2000. ${ }^{3}$ The trend since the mid-70s of declining schooling inequality combined with rising income inequality holds for all the Latin American countries in our sample except Peru (Figure 1). ${ }^{4}$ Although the overall trend is a decline in schooling inequality, there is notable variation in the schooling inequality paths of our sample countries. For example, schooling inequality in Colombia rose until the mid-90s and then started declining. In Ecuador, schooling inequality declined and then rose before declining again.

\footnotetext{
${ }^{2}$ We refer to schooling rather than education inequality throughout the paper since the inequality measure we use captures inequality in the grades of schooling attained. Education inequality is a broader concept that includes other forms of "learning" and school quality in addition to grades completed in formal education (schooling).

${ }^{3}$ For the countries included in our sample.

${ }^{4}$ The correlation between the median income Gini and median schooling Gini is -0.91 .
} 
Figure 1. Schooling and Income Inequality in Latin America 1970-2000

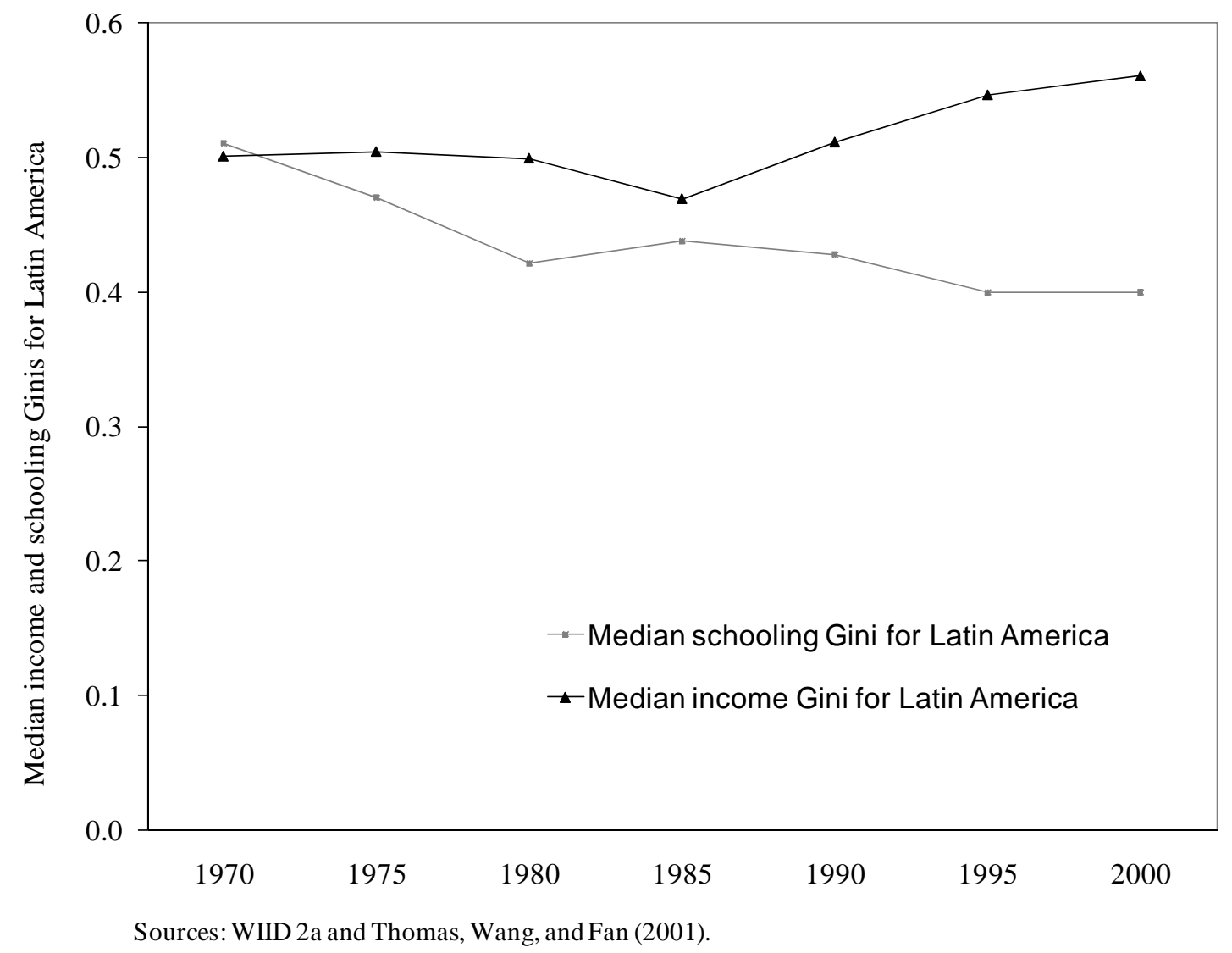

\section{Extreme Income Concentration}

Not only are income, land and schooling inequalities widespread in Latin America, but income concentration is extremely high in all countries. The income share of the top 20 percent of the population in Argentina, Brazil, Chile, Colombia, Costa Rica, Mexico, Peru, Uruguay and Venezuela was 45 percent or more in 1980 (Figure 2). In Brazil, the income share of the top 20 percent accounted for an extraordinary 62 percent of total income. By contrast, the income share of the poorest 20 percent of the population was only about 2-6 percent in each country. Income equality did not improve in the late 1990s despite economic reforms meant to promote growth and reduce poverty. Instead, the average income share of the bottom quintile was reduced from an average 4 percent to 3 percent, and the income share of the top quintile rose from roughly 57 percent to 59 percent (WIID 2a; authors' calculations). 


\section{Figure 2. Income Shares for Bottom and Top Quintiles in 1980 (percent)}

Income shares bottom and top

$20 \%$ of the population 1980

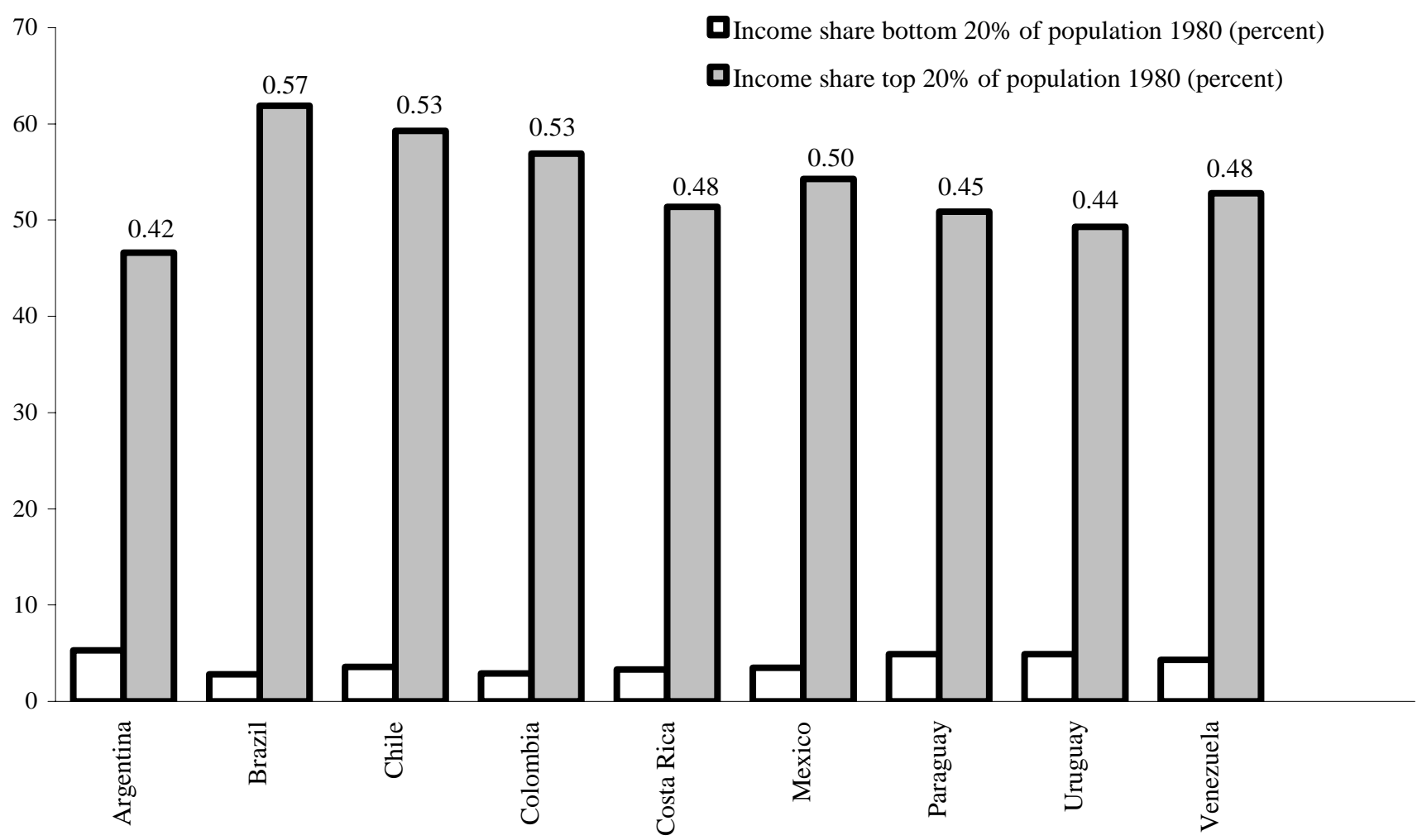

Note: Numbers above bars are 1980 income Ginis.

Source: WIID 2.0a.

Measuring Policy Changes in Latin America since the mid-80s

In this section we look at two measures of financial liberalization: the financial liberalization index created by Abiad and Mody (2005), and the structural policies index, and its subindices, constructed by Lora (2001). ${ }^{5}$

Abiad and Mody (2005) provide a comprehensive measure of the extent of financial liberalization for 41 countries including 13 from Latin America. Their index consists of seven components: directed credit/reserve requirements, entry barriers/pro-competition measures, international capital controls, privatization of banks, interest rate controls, banking

\footnotetext{
${ }^{5}$ Another measure of the extent of financial liberalization constructed by Chinn and Ito (2008) was not used in our analysis since it captures cross-border financial transactions only, not domestic financial liberalization unlike the Abiad and Mody (2005) index used in this paper.
} 
supervision and regulation, and security markets. The index ranges from zero to one, and a higher score indicates more widespread financial liberalization.

The change in the financial liberalization index from 1985 to 1995 is substantial for all Latin American countries, with several countries quadrupling their indices over the period. The average score for Latin America tripled from 0.2 in 1985 to 0.6 in 1995. In 1995 Argentina was the country that had reformed the most by this measure, while Brazil and Costa Rica had the lowest scores in the region (Table 1). By comparison, the financial liberalization index for East Asia rose from a higher initial level, 0.46 to 0.72, and for the high-income OECD countries the index increased from 0.7 to 0.9 over the same period. South Asia is lagging behind the other regions with a score of 0.4, but given its low starting level in 1985 (close to 0.1 ) reform progress, as measured by changes in the index, has been relatively fast.

The Lora (2001) structural policies index only exists for Latin American countries. It describes and measures the degree of liberalization in the areas of trade policy, taxation, privatization, financial and capital market policies, and labor markets. All Latin American countries have undertaken widespread liberalization as indicated by changes in the Lora structural policies index. The regional average on the index in 1985 was 0.33; by 1995 it had risen to 0.53 . (A score equal to 1 indicates the highest observation in the sample over the period.)

Looking at the sub-indices of the Lora index we find that it is trade and financial liberalization that dominate, with the regional average for both roughly doubling over the period 1985-1995 (also see Lora and Panizza 2002). ${ }^{6}$ As noted by Rodrik (1996, p. 18) “...it is striking how many Latin American countries have come within reaching distance of completing the items on the 'Washington Consensus' in a period of no more than a few years during the 1980s. Mexico, Bolivia, and Argentina, to cite some of the more distinguished examples, have undertaken more trade and financial liberalization and privatization within five years than the East Asian countries have managed in three decades.”

\footnotetext{
${ }^{6}$ The financial liberalization index and the financial liberalization component of Lora's structural policies index are highly correlated. The Spearman rank correlation coefficient for the financial liberalization index and Lora's financial policy sub-index is 0.73 and statistically significant at $1 \%$.
} 
Table 1. Latin America: Liberalization Indices 1985 and 1995

\begin{tabular}{|c|c|c|c|c|}
\hline & $\begin{array}{c}\text { Financial } \\
\text { liberalization index }{ }^{1} \\
1985 \\
(0-1)\end{array}$ & $\begin{array}{c}\text { Financial } \\
\text { liberalization index } 1 \\
1995 \\
(0-1)\end{array}$ & $\begin{array}{c}\text { Lora structural } \\
\text { policies index } \\
1985 \\
(0-1)\end{array}$ & $\begin{array}{c}\text { Lora structural } \\
\text { policies index } \\
1995 \\
(0-1)\end{array}$ \\
\hline Argentina & 0.10 & 0.81 & 0.34 & 0.60 \\
\hline Bolivia & 0.33 & 0.71 & 0.29 & 0.61 \\
\hline Brazil & 0.05 & 0.38 & 0.26 & 0.52 \\
\hline Chile & 0.52 & 0.71 & 0.49 & 0.58 \\
\hline Colombia & 0.05 & 0.62 & 0.29 & 0.52 \\
\hline Costa Rica & 0.10 & 0.38 & 0.31 & 0.54 \\
\hline Ecuador & 0.05 & 0.62 & 0.31 & 0.54 \\
\hline El Salvador & $\mathrm{n} / \mathrm{a}$ & $\mathrm{n} / \mathrm{a}$ & 0.35 & 0.49 \\
\hline Guatemala & 0.14 & 0.62 & 0.34 & 0.51 \\
\hline Honduras & $\mathrm{n} / \mathrm{a}$ & $\mathrm{n} / \mathrm{a}$ & $\mathrm{n} / \mathrm{a}$ & 0.49 \\
\hline Mexico & 0.14 & 0.76 & 0.40 & 0.53 \\
\hline Nicaragua & $\mathrm{n} / \mathrm{a}$ & $\mathrm{n} / \mathrm{a}$ & 0.29 & 0.57 \\
\hline Paraguay & $\mathrm{n} / \mathrm{a}$ & $\mathrm{n} / \mathrm{a}$ & 0.36 & 0.56 \\
\hline Peru & 0.19 & 0.81 & 0.28 & 0.60 \\
\hline Uruguay & 0.48 & 0.71 & 0.37 & 0.45 \\
\hline Venezuela & 0.24 & 0.43 & 0.28 & 0.48 \\
\hline \multicolumn{5}{|c|}{ Regional averages, (unweighted) ${ }^{3}$} \\
\hline Latin America $^{4}$ & 0.21 & 0.61 & 0.33 & 0.53 \\
\hline East Asia $^{5}$ & 0.46 & 0.72 & $\mathrm{n} / \mathrm{a}$ & $\mathrm{n} / \mathrm{a}$ \\
\hline South Asia ${ }^{6}$ & 0.08 & 0.37 & $\mathrm{n} / \mathrm{a}$ & $\mathrm{n} / \mathrm{a}$ \\
\hline High-Income OECD ${ }^{7}$ & 0.68 & 0.91 & $\mathrm{n} / \mathrm{a}$ & $\mathrm{n} / \mathrm{a}$ \\
\hline
\end{tabular}

Notes:

1. Abiad and Mody (2003) index. The higher the score the more reforms have been undertaken.

2. The higher the score the more reforms have been undertaken.

3. The group mean for Lora reform index in 1995 excludes Honduras.

4. The Lora index only exists for Latin American countries.

5. East Asia includes Hong Kong, Indonesia, Korea, Malaysia, Philippines, Singapore and Thailand.

6. South Asia includes Bangladesh, India, Nepal, Pakistan and Sri Lanka.

7. High-Income OECD countries are: Australia, Canada, France, Germany, Italy, Japan, New Zealand, United Kingdom and United States.

Sources: Abiad and Mody (2003), Lora (2001) and WDI (2005).

Table 1 shows regional and individual country scores for both measures. It is clear, as noted above, that there has been widespread policy change in the region, although Latin American countries began to liberalize their economies in earnest much later than countries in East Asia and high-income OECD countries. The fastest pace of change was between 1989 and 1994 (Lora and Panizza 2002). 
Figure 3 shows the progress of financial liberalization for the period 1973 to 2002 for four regions: Latin America, East Asia, South Asia and high-income OECD countries. The degree of financial liberalization as measured by the Abiad and Mody financial liberalization index was fairly similar for high-income OECD countries and East Asian countries in 1973; in contrast Latin America and South Asia had undertaken little financial liberalization at the time. In East Asia and South Asia financial liberalization has been fairly gradual, whereas in Latin America these policy changes were carried out during a much shorter period of time, beginning in the mid-1980s.

Table A1 illustrates the unevenness of liberalizing changes across Latin American countries. For example, significant changes have been carried out in Chile compared to other countries in the region in all areas except privatization. Argentina has fallen behind with respect to trade liberalization, scores the highest for financial liberalization and has the lowest score for tax policy liberalization. ${ }^{7}$

\section{Is There A Relationship between Inequality and Financial Liberalization?}

Longstanding and high inequality as is the case in Latin America may have had direct effects on whether and what liberalizing reforms were undertaken, and in what sequence, and indirect effects on reforms through its impact on the evolution of institutions that were important to the implementation of reforms.

Engerman and Sokoloff (2002) document how countries with certain initial factor endowments - abundant labor and climates and soils conducive to growing cash crops on large plantations - came to have very unequal distributions of wealth, human capital, and political power. The elite classes tended to perpetuate these inequalities through institutions that protected their interests and allowed them to appropriate public resources. As a result,

\footnotetext{
${ }^{7}$ The extent of labor market reform varies a lot across countries. The worst performers in terms of labor reform over the period 1985-1995 as measured by changes in the Lora labor market liberalization sub-index are Bolivia, Uruguay and Venezuela, and Colombia, whereas Brazil and Guatemala scored the highest on the labor market liberalization component in 1995. The degree of privatization varies substantially in the region. Whereas during the period there were hardly any privatizations in Ecuador, Paraguay and Uruguay, cumulative privatizations worth between approximately 8-15 percent of GDP were carried out in Bolivia, Peru and Argentina (Lora 2001). In terms of tax policy liberalization, Paraguay, Costa Rica and Guatemala are the countries in the region that have taken reforms the farthest.
} 
institutions that protect the rights of the general population and encourage productive economic activity did not fully develop in many Latin American countries.

Figure 3. Financial Reform by Region, 1973-2002

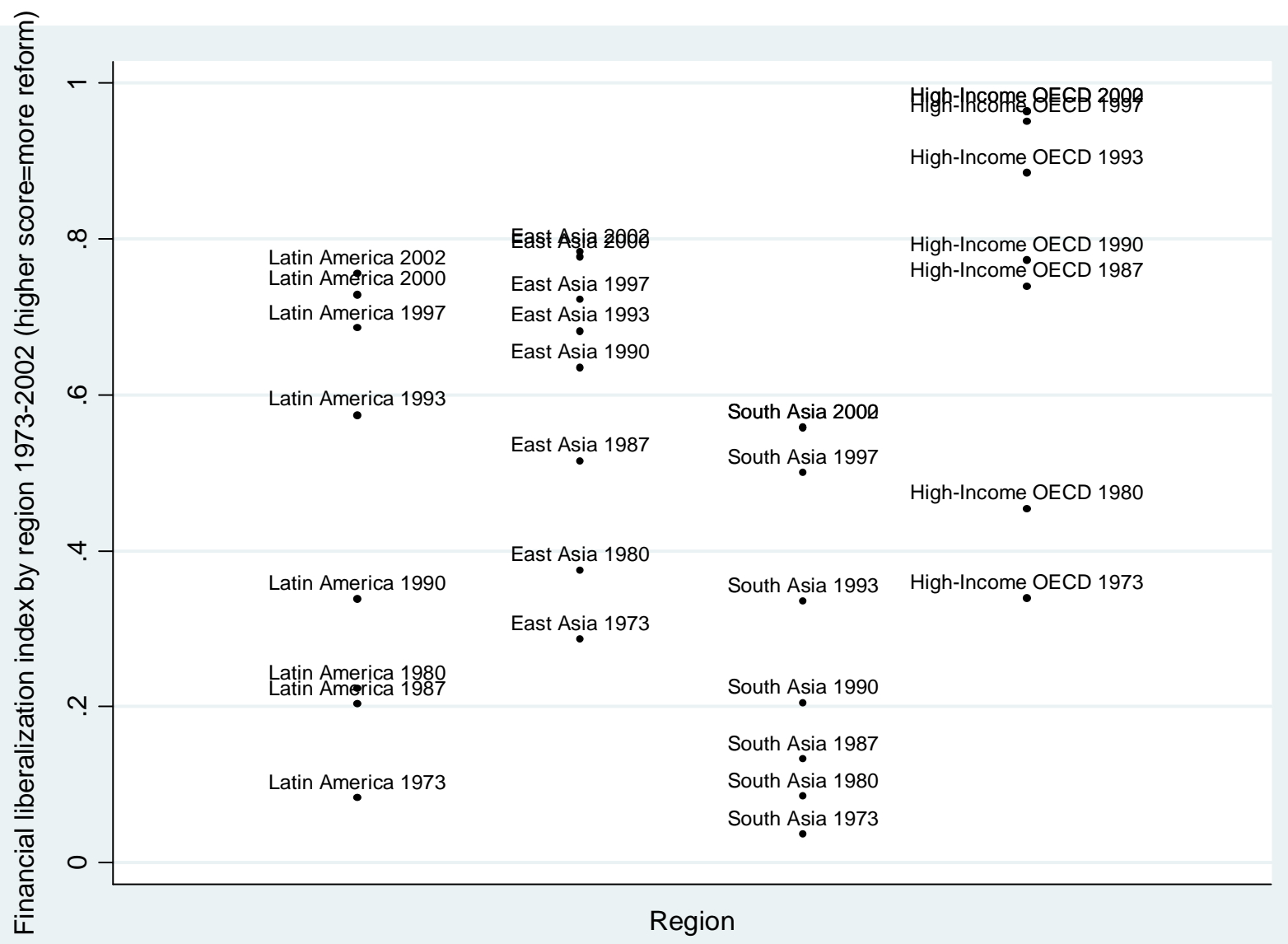

Source: Authors’ computation based on Abiad and Mody (2005).

Inequality may also have a direct negative influence on the reform process. Rodrik (1996) and Birdsall (2001) among others suggest why this may be the case. Over time structural conditions in Latin America have tended to leave political as well as economic power in the hands of a small elite. In a highly unequal setting, powerful interests are more likely to dominate politics, and will push for policies that protect their privileges rather than foster competition and growth. They are likely to support reforms, however, in the face of domestic or external circumstances beyond their control. A typical example is a bank or currency crisis when there is a need to calm the markets and bolster foreign investor confidence, or when the benefits to reform are large for the elite, and the cost of inaction substantial. 
In addition, high inequality may help trigger populist bouts of fiscal and monetary indiscipline, particularly prior to elections (IDB 1999). Also, to the extent high income inequality inhibits access to education (as shown for Latin America by Behrman et al. 2000), it may indirectly slow reform; Rodrik (1996) for example suggests that having a welleducated labor force may be necessary for reforms to work ${ }^{8}$; the history of failed conditionality in World Bank and IMF structural adjustment programs suggests that reforms unlikely to work, though promised, are seldom actually implemented ${ }^{9}$.

\section{A simple framework}

We follow Abiad and Mody (2005) in assuming that financial reform occurs in response to some combination of domestic and external shocks coupled with longstanding structural factors.

Relevant shocks in the case of Latin America might be the apparent failure of the import substitution model; the pressure from international institutions such as the International Monetary Fund (IMF) for structural reform; the increasing worldwide trend toward liberalization as the norm; and domestic or external financial and economic crises.

We include a bank crisis variable in the estimation to control for domestic shocks, with past bank crises expected to induce financial reform by forcing decision-makers to address existing weaknesses in the economy, including in financial markets. To capture external shocks we include the US interest rate. For any given domestic interest rate, we expect a higher US interest rate to be positively related to the pace of reform since it puts pressure on policymakers to address weaknesses in domestic financial markets in order to reduce capital outflows. In addition, we include an IMF program variable to test if countries with an IMF program in place have undertaken more financial liberalization. We include average GDP per capita growth in the previous five-year period to test if higher growth is associated with more financial reforms being carried out as the economic environment becomes more accommodating.

\footnotetext{
${ }^{8}$ The hypothesis that higher inequality limits growth because it leads to higher public expenditures for redistributive purposes has not borne up to empirical testing as there is no evidence that greater public expenditures as a proportion of GDP are associated with lower growth - indeed, to the contrary, greater public expenditures are seemingly associated with higher growth (see Easterly and Rebelo 1993).

${ }^{9}$ Easterly (2008) Repeated SALs; waivers of conditions
} 
To represent structural factors we use two variables: a measure of a country's quality of institutions and schooling inequality. Institutions are likely to influence reforms because the more effective a country's institutions are, the easier it is for a country to initiate and sustain policy shifts. We treat schooling inequality as a structural factor reflecting longstanding and persistent social and political arrangements associated with lack of interest on the part of elites in educating the masses (Lindert 2004), and a lack of accountability of decisionmakers to the population as a whole. ${ }^{10}$ We expect higher levels of schooling inequality to postpone financial liberalization and reduce its extent. Financial liberalization can undo privileged access to credit at repressed interest rates and increase competition in banking, and as result tends not to be in the interest of powerful industrial and other groups. Consequently, liberalization is delayed until forced by domestic or external pressures beyond the control of these influential interest groups, or until the economic circumstances change so that liberalization becomes increasingly perceived as sufficiently beneficial. We use an interaction term between the schooling Gini and the bank crisis dummy to test our conjecture that the impetus for a policy shift created by a banking crisis is lower the higher is inequality in a country.

To control for the likely possibility that countries that have liberalized more (score higher on the financial liberalization index) have less scope for further change than countries that have liberalized less we construct a liberalization gap variable. This variable is simply the maximum value of the financial liberalization index (a value of 1 ) minus the actual value of the liberalization index each period, for each country, following the approach of Fabrizio and Mody (2008).

Figure 4 is a simple scatter plot of the difference in the financial liberalization index between 1973 and 1995 against schooling Gini coefficients in 1970. There seems to be an inverse relationship between financial liberalization and schooling inequality as measured by these variables. That is, higher schooling inequality in 1970 appears to be associated with less financial liberalization having been undertaken for the countries in the sample.

\footnotetext{
${ }^{10}$ Engerman and Sokoloff (2002) suggest that the concentration of wealth in Latin America reflects its initial physical endowment combined with slavery or coercive, but sanctioned use of indigenous labor, which provided no incentive for those in power to provide education to the masses. See Lindert (2004) on the relation between democracy and universal access to schooling in $19^{\text {th }}$ century Europe and North America.
} 
We use the change in the Abiad and Mody (2005) financial liberalization index over each period as the dependent variable in our regressions for a panel of 37 developing and developed countries over the period 1975 to 2000 divided into five 5-year periods (Table A5). ${ }^{11}$

To test the relationship between inequality and liberalization we use the quinquennial schooling Gini coefficient dataset constructed by Thomas, Wang, and Fan (2001), which has not previously been used in this context. ${ }^{12}$ Average years of schooling of the adult population (15 years and older) based on grades completed also comes from Thomas, Wang, and Fan (2001). For institutional quality we use two (out of the three) equally weighted components, "political rights" and “civil liberties”, of the Freedom House index (Freedom House 2006). The index runs from 1 to 7 and a higher score indicates worse performance. The data on banking crises are 0/1 dummy variables constructed from the Bordo et al. (2001: 55) study which defines a banking crisis as a period of "financial distress resulting in the erosion of most or all of aggregate banking system capital”. Data on the US interest rate are yields on US Treasury securities at 3-month maturity from the Federal Reserve (FR 2006). Real GDP per capita growth is average period growth computed using GDP per capita in constant 2000 US dollars from the World Development Indicators (WDI 2005). Finally, the IMF program dummy variables come from the IMF’s History of Lending Arrangements (IMF various years). Summary statistics for all variables are shown in Table A2, and correlations in Table A3.

\footnotetext{
11 The reason we use the Abiad and Mody financial liberalization index rather than the financial component of the Lora structural policies index is that the latter is only available for Latin American countries, and when additional explanatory variables are added the sample size is further reduced. The correlation between the Abiad and Mody financial liberalization index and the financial liberalization component of the Lora structural policies index is high though (0.81).

${ }^{12}$ We do not run regressions with income Ginis since there are fewer observations available, which reduces the sample size notably, and for several countries only one or two observations are available. Moreover, many of the existing income Ginis are not comparable across countries since they are based on different geographic coverage, different segments of the population, and different measures of income (e.g. gross versus net).
} 


\section{Figure 4. Financial Reform and Schooling Inequality}

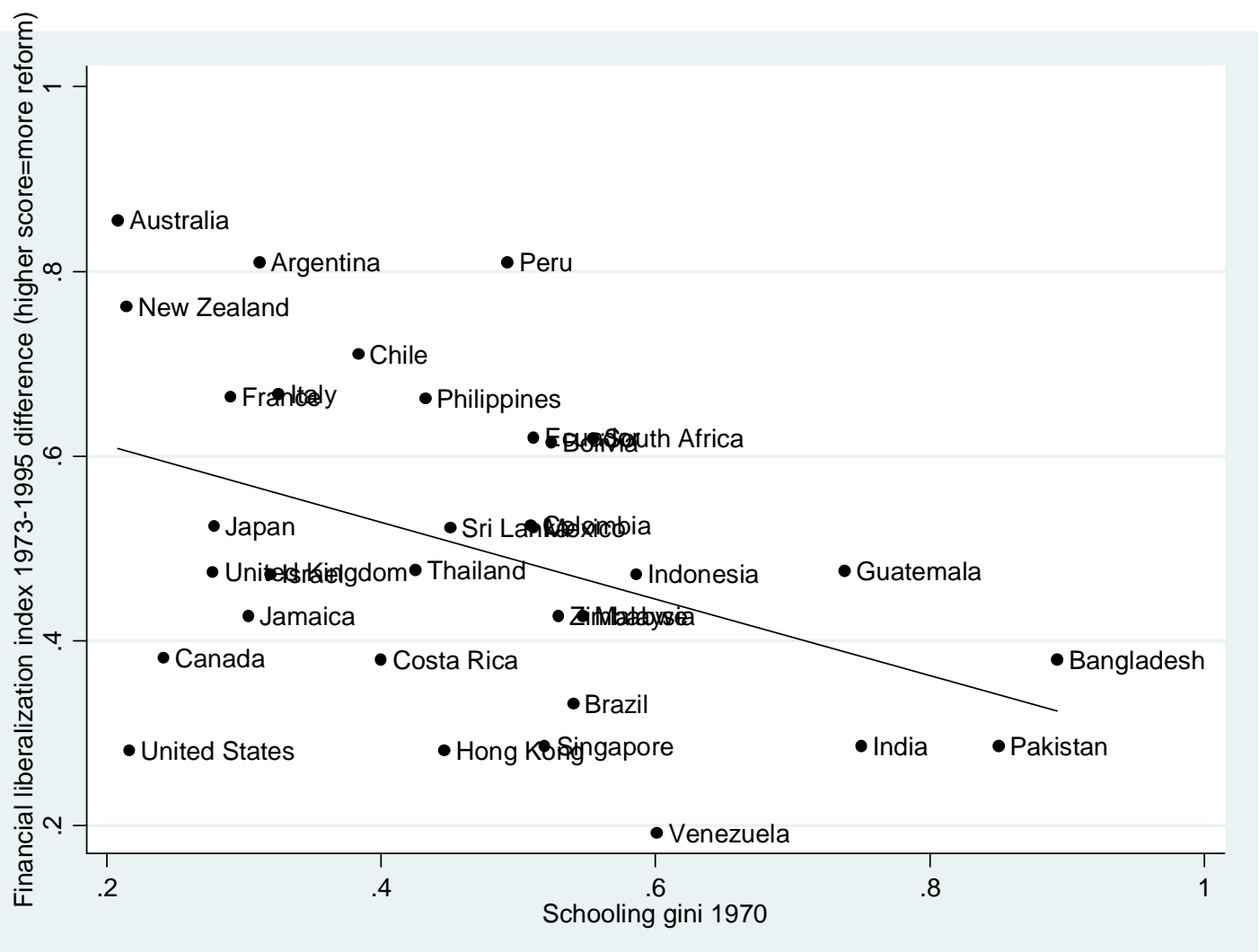

Sources: Abiad and Mody (2005), Thomas, Wang, and Fan (2001), and authors’ calculations.

\section{Regression Results}

We run five panel regressions with country fixed effects using the change in the financial liberalization index over each five-year period as the dependent variable. ${ }^{13}$ Table 2 shows the results. $^{14}$

In Table 2, the estimate of the schooling Gini coefficient is negative, and is significant in column 5 (5\% level) where average grades of schooling are also included. ${ }^{15}$

Our key result is that the interaction term between the bank crisis dummy and the schooling Gini is always statistically significant at the $5-10 \%$ level, and is negative. This supports the

\footnotetext{
${ }^{13}$ The 1st period is $1975-1979$, the 2nd, 1980-1984, the 3rd 1985-1989, the $4^{\text {th }} 1990-1994$, and the 5th $1995-$ 2000.

${ }^{14}$ Results using the level of financial liberalization as the dependent variable are available upon request; these suggest that higher schooling inequality may be associated with a lower level of financial liberalization.

${ }^{15}$ The schooling Gini and grade of schooling variables are highly negatively correlated, affecting the standard errors and therefore inference, when both variables are included in the model.
} 
idea that given a bank crisis, higher inequality in a country is associated with less financial liberalization being undertaken.

The bank crisis dummy itself, used to capture the relationship between domestic shocks and financial reform, is always positive, and statistically significant (at 5-10\%), suggesting that bank crises do provide an impetus for financial reform. The economic size of this effect is large; the move from no crisis to a crisis is associated with a 0.35 (positive) change in the liberalization index (which ranges from 0 to 1 ).

The coefficient on the liberalization gap variable is always statistically significant (1\%) and negative, suggesting that there is not convergence in financial liberalization (for our sample). That is, countries that have more scope for change do not change more on average.

The measure of institutional quality, the Freedom House index, is positive and significant at 5-10\% in all specifications. A one standard deviation increase (deterioration) in institutional quality, however, is only associated with a 0.04 improvement in the financial liberalization index. A higher score on the Freedom House index indicates lower quality institutions. Thus, contrary to our initial expectations, worse institutions are associated with more financial liberalization; Bolivia and Peru are examples of countries with relatively poor Freedom House scores where there was major financial liberalization in the 1990s..

Our measure of external shock, the US interest rate, is positive and significant (at 5\%) except for when the schooling attainment variable is included. This supports the notion that a higher US interest rate puts pressure on policymakers to undertake liberalization although the size of the effect is small: a 0.03 positive change in the financial liberalization index for a one standard deviation increase in the US interest rate. The dummy for IMF program is also positive, and is significant across specifications (at 5-10\%) suggesting that external pressure in the form of an IMF program may lead to a push for financial policy change (although the effect is small).

The real GDP per capita growth rate in the previous five-year period is never significant implying that a more accommodating economic environment, as captured by higher growth, is not associated with liberalization. 
Table 2. Regression Results with Financial Liberalization Index, First Difference

\begin{tabular}{|c|c|c|c|c|c|}
\hline \multirow{2}{*}{ Dependent variable: } & \multirow[t]{2}{*}{ (1) } & (2) & (3) & (4) & \multirow[t]{2}{*}{ (5) } \\
\hline & & Financial lil & tion index, & difference & \\
\hline \multirow[t]{2}{*}{ liberalization gap } & $-0.364 * * *$ & $-0.388 * * *$ & $-0.385 * * *$ & $-0.456 * * *$ & $-0.496 * * *$ \\
\hline & $(0.080)$ & $(0.079)$ & $(0.079)$ & $(0.084)$ & $(0.084)$ \\
\hline \multirow[t]{2}{*}{ schooling Gini (15+) } & -0.196 & -0.160 & -0.0702 & & $-1.168 * * *$ \\
\hline & $(0.30)$ & $(0.31)$ & $(0.31)$ & & $(0.44)$ \\
\hline \multirow[t]{2}{*}{ Freedom House index } & $0.0294^{* *}$ & $0.0266 * *$ & $0.0260 * *$ & $0.0225^{* *}$ & $0.0195 *$ \\
\hline & $(0.012)$ & $(0.011)$ & $(0.011)$ & $(0.011)$ & $(0.011)$ \\
\hline \multirow[t]{2}{*}{ GDP per capita growth (previous period) } & 0.00273 & 0.00300 & 0.00175 & 0.000193 & 0.000104 \\
\hline & $(0.0052)$ & $(0.0052)$ & $(0.0052)$ & $(0.0053)$ & $(0.0053)$ \\
\hline \multirow[t]{2}{*}{ IMF program (previous period) } & $0.0590 *$ & $0.0622 * *$ & $0.0646 * *$ & $0.0620 * *$ & $0.0573 * *$ \\
\hline & $(0.030)$ & $(0.028)$ & $(0.029)$ & $(0.029)$ & $(0.029)$ \\
\hline \multirow[t]{2}{*}{ US interest rate } & $0.0137 * *$ & $0.0144 * *$ & $0.0141 * *$ & 0.0102 & 0.00746 \\
\hline & $(0.0060)$ & $(0.0061)$ & $(0.0062)$ & $(0.0066)$ & $(0.0067)$ \\
\hline \multirow[t]{2}{*}{ bank crisis (previous period) } & & $0.0549 *$ & $0.201 * *$ & $0.222 * *$ & $0.186^{* *}$ \\
\hline & & $(0.029)$ & $(0.089)$ & $(0.085)$ & $(0.087)$ \\
\hline \multirow[t]{2}{*}{ interaction bank crisis \& schooling Gini } & & & $-0.352 *$ & $-0.398 * *$ & $-0.319 *$ \\
\hline & & & $(0.19)$ & $(0.18)$ & $(0.19)$ \\
\hline \multirow[t]{2}{*}{ years of schooling $\left(\mathbf{1 5}^{+}\right)$} & & & & $-0.0486 *$ & $-0.128 * * *$ \\
\hline & & & & $(0.028)$ & $(0.040)$ \\
\hline \multirow[t]{2}{*}{ Constant } & 0.157 & 0.144 & 0.112 & $0.478^{* *}$ & $1.520 * * *$ \\
\hline & $(0.11)$ & $(0.11)$ & $(0.11)$ & $(0.23)$ & $(0.44)$ \\
\hline Observations & 179 & 179 & 179 & 179 & 179 \\
\hline Number of countries & 37 & 37 & 37 & 37 & 37 \\
\hline R-squared & 0.27 & 0.29 & 0.30 & 0.32 & 0.35 \\
\hline
\end{tabular}

Note: Robust standard errors in parentheses. * significant at 10\%; **significant at 5\%; ***significant at 1\%. On the Freedom House index a

higher score indicates lower institutional quality. 


\section{Conclusion}

In a highly unequal setting, powerful interests are more likely to dominate politics, pushing for policies that protect privileges rather than foster competition and growth. It may also be the case that political elites are reluctant to push for and undertake financial liberalization until they know its likely benefits, or until they are forced to do so in the face of adverse domestic or external shocks. For our sample of 37 developing and developed countries, domestic and external shocks are associated with more financial reform being undertaken, and higher schooling inequality reduces the impetus for policy change brought on by bank crises. 


\section{References}

Abiad, Abdul and Ashoka Mody. 2005. "Financial Reform: What Shakes It? What Shapes It?” American Economic Review 95(1): 66-88.

Behrman, Jere, Nancy Birdsall, and Miguel Szekely. 2000. "Intergenerational Mobility in Latin America: Deeper Markets and Better Schools Make a Difference.” In Birdsall, N and C. Graham, Eds., New Markets, New Opportunities? Economic and Social Moblity in a Changing World. Washington, DC: The Brookings Institution and Carnegie Endowment for International Peace.

Behrman, Jere, Nancy Birdsall, and Miguel Szekely. 2007. "Economic Policy and Wage Differentials in Latin America.” Economic Development and Cultural Change 56(1): 57-97.

Birdsall, Nancy and Juan Luis Londoño. 1997. "Asset Inequality Matters: An Assessment of the World Bank’s Approach to Poverty Reduction.” American Economic Review 87(2): 32-37, Papers and Proceedings of the Hundred and Fourth Annual Meeting of the American Economic Association.

Bordo, Michael, Barry Eichengreen, Daniela Klingebiel, and Maria Soledad Martinez-Peria. 2001. "Financial Crises From the Last 120 Years. Is the Crisis Problem Growing More Severe?” Economic Policy: A European Forum 32 (April): 51-82. Web appendix http://www.economic-policy.org/pdfs/WebAppendices/bordo.pdf

Carter, Michael. 2004. "Land Ownership Inequality and the Income Distribution Consequences of Economic Growth.” In Cornia, G. A., Ed., Inequality, Poverty, and Growth in an Era of Liberalization and Globalization. New York, NY: Oxford University Press.

Chinn, Menzie, D. and Hiro Ito. 2008. “A New Measure of Financial Openness.” Journal of Comparative Policy Analysis 10(3): 309-322.

Cornia, Giovanni Andrea and Julius Court. 2001. "Inequality, Poverty and Growth in the Era of Liberalization and Globalization.” WIDER Policy Brief 4. Helsinki: World Institute for Development Economics Research.

De Janvry, Alain and Elisabeth Sadoulet. 1999. "Rural Development in Latin America: Relinking Povery Reduction to Growth.” In Lipton, M. and J. van der Gaag, Eds., Including the Poor. Washington, DC: World Bank.

Easterly, William. 2008. “Can the West Save Africa?” Brookings Global Economy and Development Working Paper 27. Washington, DC: Brookings Institution.

Easterly, William. 2002. “Inequality Does Cause Underdevelopment: New Evidence.” CGD Working Paper 1. Washington, DC: Center for Global Development.

Easterly, Willam and Sergio Rebelo. 1993. "Fiscal Policy and Economic Growth: An Empirical Investigation.” Journal of Monetary Economics 32(3): 417-458.

Engerman, Stanley, L. and Kenneth L. Sokoloff. 2002. "Factor Endowments, Inequality and Paths of Development Among New World Economies.” NBER Working Paper 9259. Boston, MA: National Bureau of Economic Research. 
Fabrizio, Stefania and Ashoka Mody. 2008. "Breaking the Impediments to Budgetary Reforms: Evidence from Europe.” IMF Working Paper 08/82. Washington, DC: International Monetary Fund.

FR. 2006. Series H.15 Selected Interest Rates. Available at http://www.federalreserve.gov/datadownload/Choose.aspx?rel=H.15

Freedom House. 2006. Freedom in the World Rankings: 1972-2005 Dataset. Available at http://www.freedomhouse.org/template.cfm?page=15

IDB. 1999. Facing Up to Inequality in Latin America. Report on Economic and Social Progress in Latin America, 1998-1999. Washington, DC: Inter-American Development Bank.

IMF. Various years. History of Lending Arrangements. Treasurer's Department. Available by country at www.imf.org

Lindert, Peter H. 2004. Growing Public: Social Spending and Economic Growth Since the Eighteenth Century. Cambridge, UK: Cambridge University Press.

Lora, Eduardo. 2001. "Structural Reforms in Latin America: What Has Been Reformed and How To Measure It.” IDB Research Department Working Paper 348. Washington, DC: InterAmerican Development Bank.

Lora, Eduardo and Ugo Panizza. 2002. "Structural Reforms in Latin America Under Scrutiny.” IDB Research Department Working Paper 470. Washington, DC: Inter-American Development Bank.

Morley, Samuel, A., Roberto Machado, and Stefano Pettinato. 1999. “Indexes of Structural Reform in Latin America.” Serie Reformas Economicas 12.

Rodrik, Dani. 1996. “Understanding Economic Policy Reform.” Journal of Economic Literature 34(1): 9-41.

Thomas, Vinod, Yan Wang, Xibo Fan. 2001. "Measuring Education Inequality: Gini Coefficients of Education for 140 countries, 1960-2000.” World Bank Policy Research Working Paper 2525, later published in Journal of Education Planning and Administration 17(1): 5-33.

WDI. 2005. World Development Indicators Database. Washington, DC: World Bank. WIID 2a. 2005. World Income Inequality Database V 2.0a, June 2005. Helsinki: World Institute for Development Economics Research. 


\section{Appendix}

Table A1. Latin America: Degree of Liberalization by Area 1985 and 1995

\begin{tabular}{|c|c|c|c|c|c|c|}
\hline 1985 & General reform index & Trade index & Financial index & Tax index & Privatization index & Labor index \\
\hline $\begin{array}{c}\text { High } \\
\text { (above regional average) }\end{array}$ & $\begin{array}{l}\text { Chile, Uruguay, } \\
\text { Paraguay, El Salvador, } \\
\text { Guatemala,__Argentina }\end{array}$ & $\begin{array}{c}\text { Bolivia, Chile, El } \\
\text { Salvador, Paraguay, } \\
\text { Argentina, Uruguay, } \\
\text { Mexico }\end{array}$ & $\begin{array}{c}\text { Chile, Uruguay, } \\
\text { Honduras, Brazil, } \\
\text { Venezuela, El Salvador, } \\
\text { Guatemala }\end{array}$ & $\begin{array}{c}\text { Uruguay, Chile, } \\
\text { Honduras, Guatemala, } \\
\text { Colombia, Ecuador, } \\
\text { Bolivia }\end{array}$ & $\mathrm{n} / \mathrm{a}$ & $\begin{array}{c}\text { Brazil, Colombia, Chile, } \\
\text { Guatemala, Peru, } \\
\text { Ecuador, Costa Rica, } \\
\text { Argentina, Nicaragua, } \\
\text { Paraguay } \\
\end{array}$ \\
\hline $\begin{array}{c}\text { Low } \\
\text { (below regional average) }\end{array}$ & $\begin{array}{c}\text { Ecuador, Costa Rica, } \\
\text { Colombia, Mexico, } \\
\text { Bolivia, Venezuela, } \\
\text { Peru, Brazil }\end{array}$ & $\begin{array}{c}\text { Venezuela, Guatemala, } \\
\text { Costa Rica, Nicaragua, } \\
\text { Peru, Ecuador, } \\
\text { Colombia, Brazil }\end{array}$ & $\begin{array}{c}\text { Bolivia, Peru, Paraguay, } \\
\text { Argentina, Mexico, } \\
\text { Costa Rica, Colombia, } \\
\text { Nicaragua, Ecuador }\end{array}$ & $\begin{array}{l}\text { Venezuela, Paraguay, } \\
\text { Costa Rica, Peru, } \\
\text { Mexico, El Salvador, } \\
\text { Argentina, Brazil }\end{array}$ & $\mathrm{n} / \mathrm{a}$ & $\begin{array}{l}\text { El Salvador, Honduras, } \\
\text { Mexico, Venezuela, } \\
\text { Uruguay, Bolivia }\end{array}$ \\
\hline Group average & 0.325 & 0.491 & 0.249 & 0.335 & $\mathbf{n} / \mathbf{a}$ & 0.546 \\
\hline
\end{tabular}

\begin{tabular}{|c|c|c|c|c|c|c|}
\hline 1995 & General reform index & Trade index & Financial index & Tax index & Privatization index & Labor index \\
\hline $\begin{array}{c}\text { High } \\
\text { (above regional average) }\end{array}$ & $\begin{array}{c}\text { Bolivia, Peru, Argentina, } \\
\text { Chile, Nicaragua, } \\
\text { Paraguay, Costa Rica, } \\
\text { Ecuador }\end{array}$ & $\begin{array}{c}\text { Bolivia, Chile, } \\
\text { Venezuela, Colombia, } \\
\text { Paraguay, Mexico }\end{array}$ & $\begin{array}{l}\text { Argentina, Bolivia, } \\
\text { Chile, Paraguay, } \\
\text { Mexico, Uruguay, } \\
\text { Nicaragua, Peru }\end{array}$ & $\begin{array}{c}\text { Paraguay, Guatemala, } \\
\text { Costa Rica, Ecuador, } \\
\text { Venezuela, Chile, } \\
\text { Honduras, El Salvador, } \\
\text { Bolivia }\end{array}$ & $\begin{array}{c}\text { Bolivia, Mexico, Peru, } \\
\text { Nicaragua, Argentina }\end{array}$ & $\begin{array}{c}\text { Colombia, Brazil, } \\
\text { Guatemala, Chile, Peru, } \\
\text { Ecuador, Costa Rica, } \\
\text { Paraguay, Nicaragua, } \\
\text { Argentina }\end{array}$ \\
\hline $\begin{array}{c}\text { Low } \\
\text { (below regional average) }\end{array}$ & $\begin{array}{l}\text { Mexico, Colombia, } \\
\text { Brazil, Guatemala, } \\
\text { Honduras, El Salvador, } \\
\text { Venezuela, Uruguay }\end{array}$ & $\begin{array}{l}\text { Ecuador, Uruguay, Peru, } \\
\text { Honduras, Nicaragua, El } \\
\text { Salvador, Argentina, } \\
\text { Brazil, Guatemala, } \\
\text { Costa Rica }\end{array}$ & $\begin{array}{l}\text { Costa Rica, Venezuela, } \\
\text { El Salvador, Ecuador, } \\
\text { Colombia, Brazil, } \\
\text { Guatemala, Honduras }\end{array}$ & $\begin{array}{c}\text { Brazil, Uruguay, } \\
\text { Colombia, Peru, } \\
\text { Nicaragua, Mexico, } \\
\underline{\text { Argentina }}\end{array}$ & $\begin{array}{l}\text { Honduras, Venezuela, } \\
\text { Brazil, Colombia, Chile, } \\
\text { Costa Rica, Ecuador, } \\
\text { Paraguay, Uruguay, } \\
\text { Guatemala, El Salvador }\end{array}$ & $\begin{array}{l}\text { Honduras, El Salvador, } \\
\text { Mexico, Venezuela, } \\
\text { Uruguay, Bolivia }\end{array}$ \\
\hline Group average & 0.536 & 0.878 & 0.651 & 0.469 & 0.149 & 0.534 \\
\hline
\end{tabular}

Note: Within boxes, countries with the highest index are listed first, followed by the country with the second highest index etc.

Source: Lora (2001). 
Table A2. Summary Statistics

\begin{tabular}{|c|c|c|c|c|c|c|}
\hline & mean & median & $\begin{array}{l}\text { standard } \\
\text { deviation }\end{array}$ & $\min$ & $\max$ & observations \\
\hline reform gap & 0.49 & 0.48 & 0.29 & 0.00 & 1.00 & 179 \\
\hline years of schooling $(15+)$ & 6.5 & 6.0 & 2.5 & 1.9 & 12.1 & 179 \\
\hline bank crisis & 0.2 & 0.0 & 0.4 & 0.0 & 1.0 & 179 \\
\hline freedom house index & 3.1 & 3.0 & 1.5 & 1.0 & 7.0 & 179 \\
\hline US interest rate & 7.6 & 7.5 & 2.2 & 5.5 & 11.6 & 179 \\
\hline GDP per capita growth $(\%)$ & 1.99 & 1.95 & 2.44 & -4.39 & 8.63 & 179 \\
\hline
\end{tabular}

Table A3. Correlations

\begin{tabular}{|c|c|c|c|c|c|c|c|c|c|}
\hline & $\begin{array}{c}\text { financial } \\
\text { liberalization } \\
\text { index }\end{array}$ & $\begin{array}{c}\text { reform } \\
\text { gap }\end{array}$ & $\begin{array}{c}\text { schooling } \\
\text { Gini } \\
\left(15^{+}\right)\end{array}$ & $\begin{array}{c}\text { years of } \\
\text { schooling } \\
(15+)\end{array}$ & $\begin{array}{l}\text { bank } \\
\text { crisis }\end{array}$ & $\begin{array}{c}\text { freedom } \\
\text { house } \\
\text { index }\end{array}$ & $\begin{array}{c}\text { IMF } \\
\text { program }\end{array}$ & $\begin{array}{c}\text { US } \\
\text { interest } \\
\text { rate }\end{array}$ & $\begin{array}{c}\text { GDP per } \\
\text { capita growth } \\
(\%)\end{array}$ \\
\hline financial liberalization index & 1 & & & & & & & & \\
\hline reform gap & -0.87 & 1.00 & & & & & & & \\
\hline schooling Gini (15+) & -0.62 & 0.59 & 1.00 & & & & & & \\
\hline years of schooling $(15+)$ & 0.67 & -0.65 & -0.92 & 1.00 & & & & & \\
\hline IMF program & -0.25 & 0.24 & 0.17 & -0.22 & 0.20 & 0.17 & 1.00 & & \\
\hline US interest rate & -0.55 & 0.55 & 0.13 & -0.18 & 0.09 & 0.11 & 0.01 & 1.00 & \\
\hline GDP per capita growth (\%) & 0.07 & -0.13 & -0.01 & 0.05 & -0.08 & 0.18 & -0.15 & 0.07 & 1.00 \\
\hline
\end{tabular}


Table A4. Sample countries

\begin{tabular}{ll}
\hline Argentina & Jamaica \\
Australia & Japan \\
Bangladesh & Korea \\
Bolivia & Malaysia \\
Brazil & Mexico \\
Canada & New Zealand \\
Chile & Pakistan \\
Colombia & Peru \\
Costa Rica & Philippines \\
Ecuador & Singapore \\
Egypt & South Africa \\
France & Sri Lanka \\
Germany & Thailand \\
Ghana & Turkey \\
Guatemala & United Kingdom \\
India & United States \\
Indonesia & Uruguay \\
Israel & Venezuela \\
Italy & \\
\hline
\end{tabular}


Table A5. Variable Descriptions and Sources

\begin{tabular}{|c|c|c|}
\hline Variable & Description & Source \\
\hline $\begin{array}{l}\text { financial liberalization } \\
\text { index }\end{array}$ & $\begin{array}{l}\text { The Abiad and Mody (2005) financial liberalization } \\
\text { index consists of seven components: directed } \\
\text { credit/reserve requirements, entry barriers/pro- } \\
\text { competition measures, international capital controls, } \\
\text { privatization of banks, interest rate controls, banking } \\
\text { supervision and regulation, and security markets. }\end{array}$ & Abiad and Mody (2005). \\
\hline schooling Gini (15+) & Schooling Gini for population 15 years and older. & Vinod, Wang, and Fan (2001). \\
\hline $\begin{array}{l}\text { average years of } \\
\text { schooling }\left(15^{+}\right)\end{array}$ & $\begin{array}{l}\text { Average years of schooling (based on grade } \\
\text { completed) for adult population. }\end{array}$ & Vinod, Wang, and Fan (2001). \\
\hline GDP per capita growth & Average real period GDP per capita growth, percent & $\begin{array}{l}\text { World Income Inequality Database V 2.0a } \\
\text { (2005), } \\
\text { http://www.wider.unu.edu/wiid/wiid.htm }\end{array}$ \\
\hline freedom house index & $\begin{array}{l}\text { Equally weighted average of the "political rights" and } \\
\text { the "civil liberties" components of the Freedom House } \\
\text { index. The index lies in the range } 1 \text { to } 7 \text { and a higher } \\
\text { score indicates worse performance. }\end{array}$ & $\begin{array}{l}\text { Freedom House (2006), } \\
\text { http://www.freedomhouse.org/template.cfm?page } \\
=15\end{array}$ \\
\hline bank crisis & $\begin{array}{l}\text { Dummy equal to one if systemic banking crisis } \\
\text { (defined as much or all of bank capital being } \\
\text { exhausted), zero otherwise. }\end{array}$ & $\begin{array}{l}\text { Bordo, Eichengreen, Klingebiel, and Martinez- } \\
\text { Peria (2001), } \\
\text { http://www.economic- } \\
\text { policy.org/pdfs/WebAppendices/bordo.pdf }\end{array}$ \\
\hline US interest rate & 6-month US T-bill rate, percent. & $\begin{array}{l}\text { U.S. Federal Reserve Board, Data Download } \\
\text { Program (2007). } \\
\text { http://www.federalreserve.gov/datadownload/def } \\
\text { ault.htm }\end{array}$ \\
\hline IMF & $\begin{array}{l}\text { Dummmy variable equal to one if IMF program, zero } \\
\text { otherwise. }\end{array}$ & $\begin{array}{l}\text { IMF. Various years, } \\
\text { http://www/imf.org }\end{array}$ \\
\hline reform gap & $\begin{array}{l}\text { Maximum value of the financial liberalization index } \\
\text { (1) minus actual score on the financial liberalization } \\
\text { index in each period. }\end{array}$ & Abiad and Mody (2005), authors' computations. \\
\hline
\end{tabular}

